JURNAL BASICEDU

Research \& Learning in Elementary Education

https://jbasic.org/index.php/basicedu

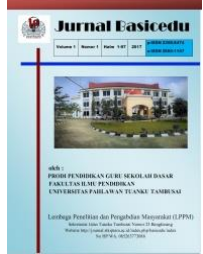

\title{
LITERACY SKILLS DEVELOPMENT THROUGHT MESSANGERS' STORIES AS THE SPIRITUAL BEHAVIOUR REALISATION IN ELEMENTARY SCHOOL
}

\author{
Mayarnimar $^{1}$, Taufina ${ }^{2}$, Muhammadi ${ }^{3}$, Muhammad Ilham Syarif ${ }^{4}$ \\ Universitas Negeri Padang, Sumatera Barat, Indonesia ${ }^{1,2,3,4}$ \\ Email: mayarnimar@fip.unp.ac.id ${ }^{1}$, taufina @ fip.unp.ac.id ${ }^{2}$, muhammadi@ fip.unp.ac.id ${ }^{3}$, \\ mdilhamsf@gmail.com ${ }^{4}$
}

\begin{abstract}
Abstrak
Penelitian ini bertujuan mengembangkan pembelajaran literasi dengan menggunakan cerita Nabi untuk membentuk sikap spiritual yang bagus yang valid, praktis, dan efektif di sekolah dasar (SD). Metode yang digunakan di dalam penelitian ini adalah metode Plomp dan digabungkan dengan Gravemeiyer dan Cobb. Di dalam penelitian ini terdiri tiga tahap diantaranya tahap awal (Premaring phase), prototype, dan tahap penilain ( Assesment phase). Populasi di dalam penelitian ini adalah kelas 2 Sekolah dasar di kota Padang. Hasil dari penelitian ini adalah di dapatkan 95,5\% valid. Literasi dengan menggunakan cerita nabi menghasilkan praktis hal ini didukung hasil angket guru $87,5 \%$ dan siswa 83,3\%. Pembelajaran siswa di implementasi efektif karena siswa mampu memilih dan mengimplementasikan karakter spiritual dengan mereka mampu menuliskan sikap spiritual dari cerita yang mereka baca.
\end{abstract}

Kata Kunci : literasi, cerita nabi, pengembangan

\begin{abstract}
The aim of this study is development literacy by using the story of the prophet to make a good spiritual attitude valid for elementary school, practice, and effective. Methods This study uses the development of research of Plomp. This study is a research design that combines Plomp models with models Gravemeijer \& Cobb, the which consists of 3 phases roommates preliminary studies (Preliminary research/preparing for the experiment), phase of development (Development or prototyping phase/design experiment) and assessment phase ( assessment phase/retrospective analysis), This population is elementary school in Padang. The Results Showed that the learning literacy with using the story of the prophet to made a good spiritual attitude for elementary students gets $95.5 \%$ is Valid. literacy with using the story of the prophet to made a good spiritual attitude get to practice for elementary student questionnaire teachers get $87.5 \%, 83.3 \%$ of the student questionnaire. literacy with using the story of the prophet to made good spiritual attitude for an elementary student can get effective Because student chose how to implement a spiritual good in their attitude after literacy lives with the story of the prophet.
\end{abstract}

Keywords: literacy, story of prophet, development

@ Jurnal Basicedu Prodi PGSD FIP UPTT 2019

$\square$ Corresponding author :

Address :

Email

ISSN 2580-3735 (Media Cetak)

Phone ISSN 2580-1147 (Media Online) 


\section{INTRODUCTION}

Most Literate Nations, compiled by Central Connecticut State University in 2016, ranking literacy Indonesia are the second bottom of the 61 countries studied. This fact is based on the aspect. Among other things, libraries, newspapers, educational system input, the output of the education system, and the availability of computers. The data describe that the condition of interest in reading the Indonesian nation was quite apprehensive. There needs to be an effort to deal with such matters, including the provision of reading materials for reading in learning. As stipulated in Permendikbud Number 23 the Year 2015 concerning Budi Character Education that there are activities of reading 15 minutes before learning, reading literacy movement needs to be done to form the quality of students eligible internationally.

Reading literacy focused on reading comprehension includes four main studies, namely: (1) reading skills; (2) implementation, training, and establishment of readings; (3) The process of reading; and (4) the text used in reading (UNESCO, 2005: 447). Looked at in terms of reading literacy skills of reading comprehension leads to the technique used. Noting the reading comprehension techniques will give birth to the quality of students' reading better. Mechanical reading the correct understanding and proper implementation (Saddhono and Slamet, 2012: 66). The reading process consists of three stages: (1) privacy, (2) when read, and (3) after reading (Somadayo, 2011: 35-38). The reading process must be accompanied by the proper use of the reading text.

Reading literacy teaching materials referring to the availability of reading text. Teaching materials developed with the right strategy will foster creative endeavor own invention the content of reading by students. The process of the invention is, in addition to knowing the type of text to be read can also be done by making predictions and accurately summarize the content of reading. Reading text provided must be using a pattern language understood by students and teaches students to recognize the spiritual familiar social environment. Making it easier for students to interact according to the social and spiritual development of their environment.

Based on the needs analysis through observation and interview respondents found several problems. First, the teaching materials used less describe the process of learning the proper reading literacy, so that the learning process is rarely accomplished following the correct reading. Learning to read is rarely preceded by a process of predicting the content of reading because not effective in the teaching materials used by students (Triplett, 2002: 123). Second, reading comprehension instructional materials used in SD still less bring students to get to know the spiritual attitude. As a result, students rarely know the spiritual attitude, especially the story of the prophet. Third, the teaching materials that are used rarely use the story of the prophet as a learning medium that is useful to improve the students' attitude. Fourth, most students read the text that reads voice, so that her lips moving or moving. This is in line with the results of the study in 2006 conducted by the PISA (Program for International Student Assessment) (Alwasilah, 2012: 171).

Based on these problems, need to do research and development to improve literacy reading students in the planting of the value of spiritual attitudes of "Developing Reading Skills by using the story of the prophet as Investment Attitude Spiritual for Elementary Students" which students are expected to pay more attention to the reading text and raise the curiosity and has a special attraction to the reading text. Goals to be 
achieved in this research is the realization of innovation and completion of reading literacy development of teaching materials by using the story of the prophet as a form of spiritual attitudes planting for elementary students who need to be realized in real-life students. The findings of this study of reading literacy teaching materials by using the story of the prophet valid, practical, and effective in SD.

\section{METHODS}

Development models used in this research is the development model adopted Plomp from McKenney development model. Plomp Model consists of three stages: (1) Preliminary analysis (preliminary research), (2) design (prototyping phase), and (3)assessment (assessment stage) (Plomp, 2013: 19).

Preliminary analysis phase (Preliminary research) conducted a needs analysis, curriculum analysis, and the characteristics of learners. Followed by the design stage (prototyping phase) with the design of the product is made. The design of the finished product is evaluated by a teacher who used it during the experiment. Furthermore, it continued with evaluated by experts commonly called the validation process. The results of consultations with specialists serve as input for the revision of the product. Once revised, the evaluation of individuals and small groups, followed by testing to the selected schools. When tested, observed use and enforceability of teaching materials. After the product was revised based on feedback from the teacher or observer, followed by trials in the next school to see the effectiveness of the product(assessment stage), At the end of the process, prompted a response from teachers and learners, and tested the effectiveness of the use of teaching materials (Tessmer in Plomp, 2013: 36).
Model development is selected in each study has its own advantages that can serve as the basis and reference for model selection is done. The advantages possessed by the model Plomp include: (1) more appropriately used for the development of teaching materials, (2) description is a complete and systematic, (3) before testing, teaching materials developed revised its own and consulted in advance on the expert/experts, and (4) the evaluation of individuals and small groups prior to field testing. The procedure is adapted from the model development Plomp development with the stages that must be done in every development as the previous descriptions. The schematic design of research and development can be seen in the following figure 1

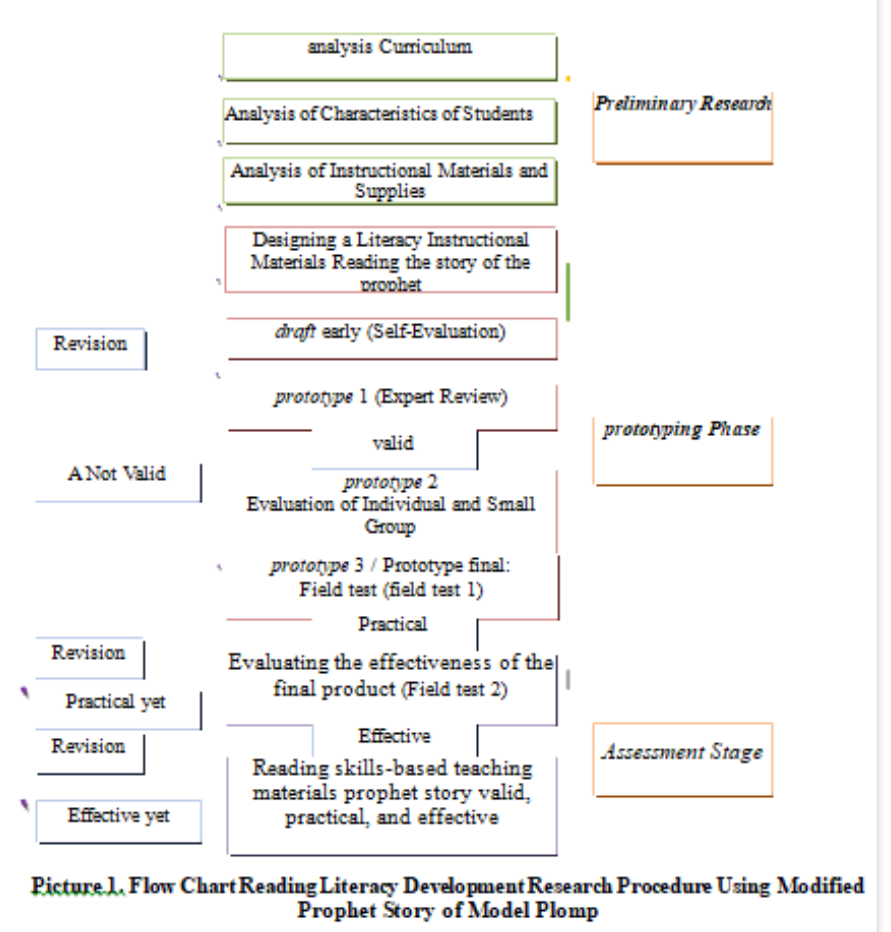

\section{RESULTS AND DISCUSSIONS}

This study was designed in a multi-year study, which is for 2 (two years). Given the wide scope of the problem, various studies ask in this study can be studied by several researchers, both parties involved in this study, as well as other researchers. This study aims to: (1) assess the profile development and develop literacy teaching materials read by using the story of the prophet as 
a form of spiritual attitudes planting for elementary students. (2) assessing the practicalities of the development of literacy read by using the story of the prophet as a form of spiritual attitudes planting for elementary school students, and (3) assess the effectiveness of the implementation of the development of literacy through reading by using the story of the prophet as a form of spiritual attitudes planting for elementary students.

Specific targets to be achieved in the first year of study, reviewing the description of reading literacy development profile need to use the story of the prophet as a form of spiritual attitudes planting for elementary students both practical needs and strategic needs. The first year of the products with a draft of literacy teaching materials read by using the story of the prophet as a form of spiritual attitudes planting for elementary students with a valid category.

Table _. Results of Validation Literacy Instructional Materials Reading Prophet Entire

\begin{tabular}{|c|c|c|c|c|}
\hline \multicolumn{5}{|c|}{ Story } \\
\hline No & Aspect & amount & Arerage & Category \\
\hline 1. & $\begin{array}{l}\text { feasibility of } \\
\text { Contents }\end{array}$ & 232 & 3.86 & very Valid \\
\hline 2. & linguistic & 14 & 3.50 & very Valid \\
\hline 3. & Presentation & 19 & 3.80 & very Valid \\
\hline 4. & Kegrafikaan & 25 & 3.57 & very Valid \\
\hline & Arerage & 3.82 & & Very valid \\
\hline
\end{tabular}

According to table 1 shows that the average reading literacy resource validation as a whole was 3.82 with a very valid category. Thus, we can conclude that reading literacy-based instructional materials to use stories prophets and companions have been valid.

The second-year study, conducted for the development of literacy read by using the story of the prophet as a form of spiritual attitude planting for elementary students. Based on reading literacy books are arranged in the first year, product trials to look at the practicalities and effectiveness.

Specific targets to be achieved in the second year of research is) reviewing the effectiveness of the implementation of the development of literacy through reading by using the story of the prophet as a form of spiritual attitudes planting for elementary students. This is done by researching the school.

This research was conducted at the Experimental School of Padang. The study was conducted on August 22, 2019, August 23, 2019, 5 September 2019, September 6, 2019, and September 10, 2019. The study was conducted in the classroom and outside the classroom.

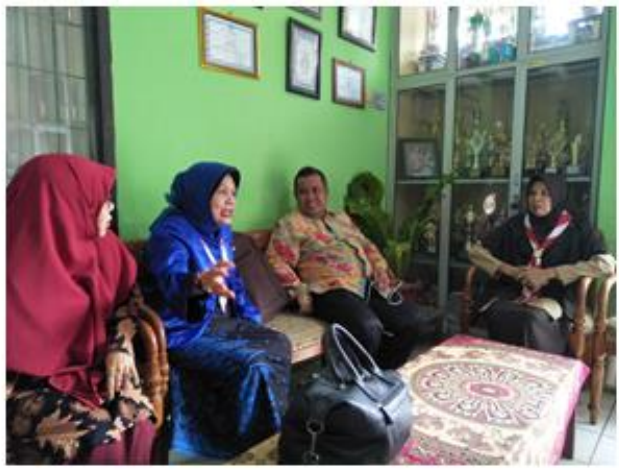

Picture 2.Photos of Reading Literacy Gathering and Discus By. Using The story of Prophet For Planting Efforts Spiritual Attitude with Teachers and Headmaster

At this meeting, the lecturer gives understanding to the teacher that it is very important for learning in primary schools should culture in improving the character of the students, because today a national character so easily influenced by outside cultures. Thus making the moral degradation in Indonesia. Literacy by using the story of the prophet is effective and efficient in changing the character of the students become positive characters

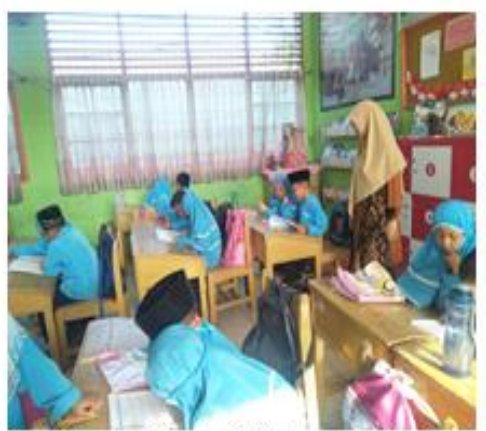

Picture 3. Student Reading Textbook Literacy With Stories of the Prophet 
2034 Literacy skill development througtht messangers stories as the spiritual behaviour realisation in elementary school-Mayarnimar, Taufina, Muhammadi, Muhammad Ilham Syarif

At its next meeting the students are given the opportunity 15 minutes to read a textbook that has been provided. After reading the book students are given the opportunity to retell the stories that have been read

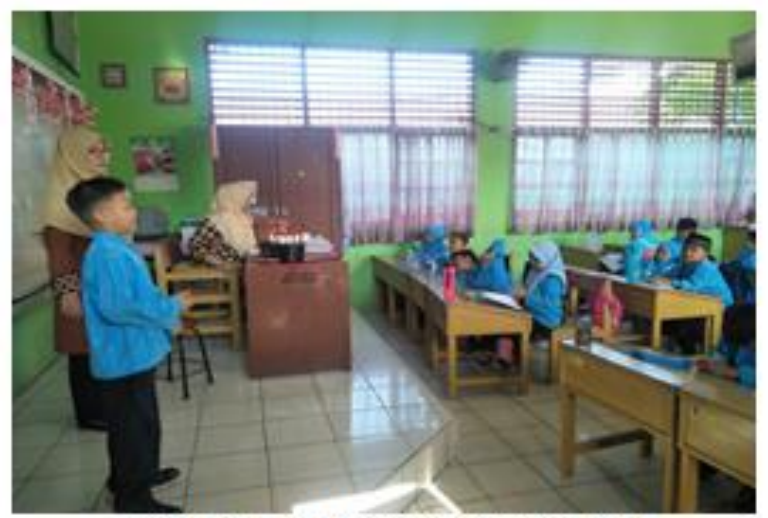

Picture 4 . Students Stories after read

In this activity, students are very enthusiastic about retelling the stories they've read. Students read stories such as the story of the prophet Ibrahim's story, the story of Noah. After recounting the activities of students define good character and characters were not good.

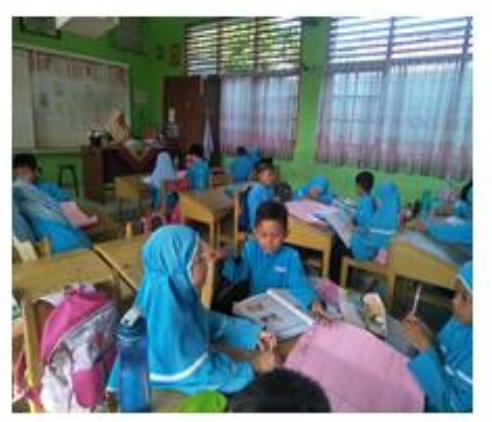

Picture 5. Photo Students Wh/n Discussing Determining Good Character

The teacher divides the students into 8 groups. Each group received single cardboard to write on the discussion of both existing karate stance in the story of the prophet and karate are not well in the story they've read.

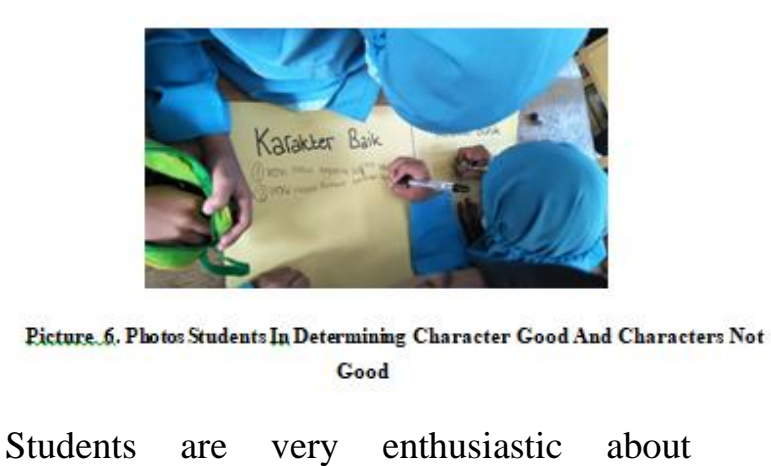

determining the character contained in the story. Even students who write the name of the character contained in the stories they've read. The karate written by students include:

1.Karakter affection

2. The character of family love

3. Characters do good to others

4. Character patient

5. Character is not easy submitters

6. The character must always remember to Allah SWT

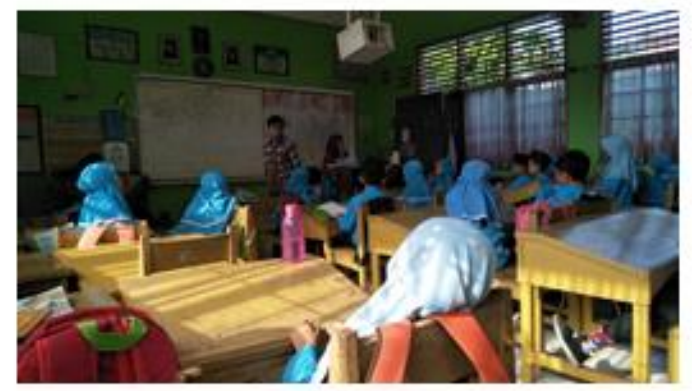

Picture 7, Storytelling Students Hear From Mr. Ridha

At the third meeting of the story of the Prophet story by Mr. Ridha. At this event, Mr. Ridha gives example good character and bad karate. So that students can distinguish the exemplary attitude and attitude that is not replicated in daily life

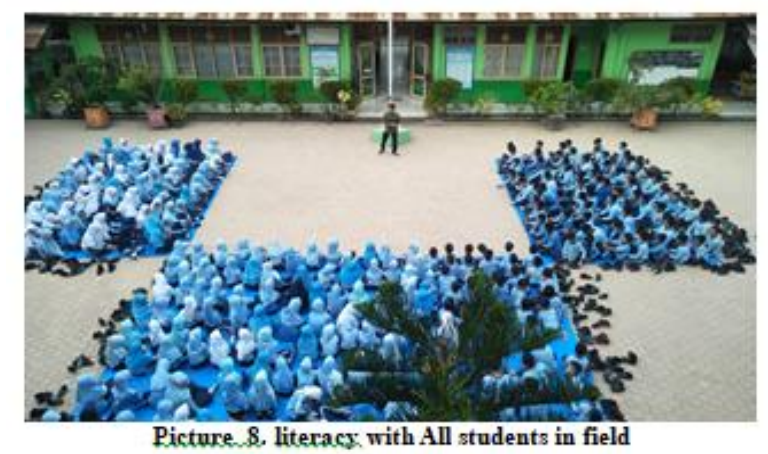


At the fourth meeting, with the story of the prophet literacy activities held outside the classroom involving the entire class. The story told is the story of Prophet Ayub US. In this activity, students are very interested in the story of the prophet. It is seen by actively asking and students' responses to the story told.

The test results practicalities of using questionnaires to teachers and students. Reading literacy development by using the story of the prophet as a spiritual attitude planting effort for elementary students who practicals with the acquisition of $87.5 \%$ of teachers and $83.3 \%$ for the acquisition of the students.

\section{CONCLUSIONS}

Reading literacy development by using the story of the prophet as a spiritual attitude planting effort for elementary students is a multi-year study that was conducted over 2 years. In detail in year-1 has produced the following matters. Reading literacy development by using the story of the prophet as a spiritual attitude and instill valid for elementary students with the acquisition of $95.5 \%$. Reading literacy development by using the story of the prophet as a spiritual attitude planting efforts for elementary students who praktikalis with the acquisition of $87.5 \%$ of teachers and $83.3 \%$ for the acquisition of the students. Reading literacy development by using the story of the prophet as a spiritual attitude and instill effective for elementary students with a proven student is able to write a good spiritual attitude of the story of the prophet who already read and didongengkan by teachers.

Based on the research that has been conducted in the second year suggested the following things:

For education, it should enrich the findings of the thematic field of learning theory can be used as a reference for reading literacy development by using the story of the prophet as a spiritual attitude planting effort.

For other researchers, should development literacy read by using the story of the prophet as planting efforts and develop a spiritual attitude applicative guide for teachers to develop materials. Thus, the model develops literacy read by using the story of the prophet as a spiritual attitude planting effort can be disseminated and applied in the national thematic learning to achieve national education goals to the fullest.

\section{REFERENCES}

Abidin, Jonah. 2012. Based Language Learning Character Education. Bandung: Refika Aditama.

Alwasilah, A. Chaedar. Anyway 2012. Engineering Literacy. Bandung: Main Book Qibla.

Baleiro, Rita. 2011. A Definition of Literary Literacy: A Content Analysis of Literature Syllabuses and Interviews with Portuguese Lecturers of Literature. Journal of New Horizons in Education, (Online), Volume 1, Issue (http://www.tojned.net/pdf/tojnedv01i0402.pdf, Accessed March 25, 2016.

Binkley, Marilyn and Williams, Trevor. 1996 Reading Literacy in the United States: Findings From the IEA Reading Literacy Study. Washington: Government Printing Office.

Burke, Jim. 2010. What's the Big Idea ?: QuestionDriven Units to Motivate Reading, Writing, and Thingking. USA: Heinemann.

Bromley, Karen, Linda Irwin De Vitis, and Marcia Modlo. 1999. 50 Graphic Organizers for Reading, Writing, \& More. USA: Scholastic.

Drapeau. 2001. The Use of Graphic Organizers to Enhance Thinking Skills in The Learning of Economics. Hong Kong: Education Dept.

Geske, Andrejs and Ozola, Antra. 2008. Factors Influencing Reading Literacy at the Primary School Level. Journal Problems of Education in the 21st Century, (online) Vol. 6, (http://www.jbse.webinfo.lt/7177.Geske.pdf, Accessed 11 April 2016). 
Keefe, Elizabeth B. and Copeland, Susan R. 2011. What Is Literacy? The Power of a Definition. Journal of Research and Practice for Persons with Severe Disabilities, (Online), Vol. $36 \quad$ No. 3-4, (http://www.pealcenter.org/images/What_is _Literacy.pdf, Accessed March 25, 2016).

McConnell, Carolyn. 2011. The Essential Questions. USA: Scholastic Inc.

Ngaka, Willy and Masaazi, Fred Masagazi. 2015. Participatory Learning Literacy in an African Context: Perspectives from the Ombaderuku Primary School in the Arua District, Uganda. Journal of Language and Literacy Education (Online), Vol. 11 No. 1, (http://jolle.coe.uga.edu/wpcontent/uploads/2015/04/NgakaMasaazi_Fin al-.pdf, Accessed February 13, 2016).

Nieto, Sonia. 2013. Language, Literacy, and Culture: Aha! Moments in Personal and Sociopolitical Understanding. Journal of Language and Literacy Education (Online), $\begin{array}{llll}\text { Vol. } & 9 & \text { No. } & \end{array}$ (http://files.eric.ed.gov/fulltext/EJ1008170.p df, Accessed February 13, 2016).

Nieto, Sonia. 2013. Language, Literacy, and Culture: Aha! Moments in Personal and Sociopolitical Understanding. Journal of Language and Literacy Education (Online), $\begin{array}{llll}\text { Vol. } & 9 & \text { No. } & 1 \text {, }\end{array}$ (http://files.eric.ed.gov/fulltext/EJ1008170.p df, Accessed February 13, 2016).

Pappas, Christine C. Kiefer, Barbara Z., and Levstik, S. 1990. An integrated Llinda Language in the Elementary School Perspective: Theory into Action. New York: Longman.

Rahim, Farida. 2007. Teaching Reading in Primary Schools. Jakarta: Earth Literacy.

Saddhono, Kundharu and Slamet, St.Y. 2012. Improving Language Skills Indonesia (Theory and Applications). Bandung: Karya Putra Darwati.

Somadayo, Samsu. 2011. Strategies and Techniques Learning Reading. Yogyakarta: Graha Science.

Soedarso. 2010. Speed Reading: Fast and Effective Reading System. Jakarta: Grmedia Main Library.

Tarin, HG 2008. Reading as sutau Language Skills. Bandung: Angkas.
Taufina. 2015. Language Skills and Indonesian Literature Appreciation in SD. Padang: Sukabina Press.

Triplett, Cheri Foster. Dialogic 2002. Responsiveness: Toward Synthesis, Complexity, and holism in Our Reponses to Young Literacy Learners. Journal of Literacy Research, (Online), Vol. 34 No. 1, (http://jlr.sagepub.com/content/34/1/119.full .pdf+html, Accessed February 13, 2016).

Uno, Hamzah B. 2007. Creating Learning Model Learning Process Creative and Effective. Jakarta: Earth Literacy. 